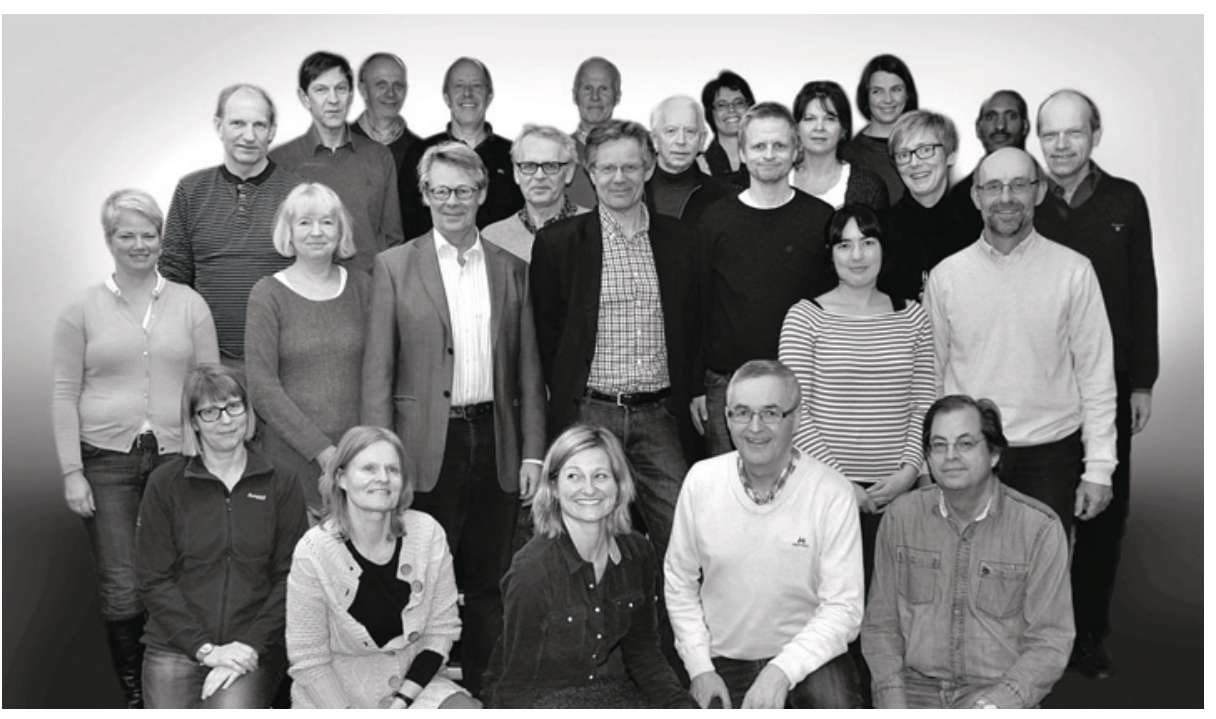

IBSEN-gruppen. Foto Neda Saghlam

\title{
Ikke økt dødelighet ved Crohns sykdom
}

Pasienter med Crohns sykdom dør ikke tidligere enn normalbefolkningen. Det viser en ny norsk studie.

Populasjonsbaserte studier fra årene 1970-90 viste at pasienter med Crohns sykdom hadde en noe redusert livslengde sammenliknet med normalbefolkningen. Norske forskere har nå fulgt pasienter med Crohns sykdom fra fylkene Aust-Agder, Telemark, Oslo og Østfold i 20 år (1). 237 pasienter diagnostisert med sykdommen i perioden 1.1. 1990-31.12. 1993 ble prospektivt inkludert i studien. De ble aldersog kjønnsmatchet med 25 personer fra den generelle befolkning i de samme fylkene. Median alder ved inklusjonstidspunktet var 27 år for menn og 29 år for kvinner. Oppfølgingen omfattet intervju, kliniske og biokjemiske undersøkelser, koloskopier med biopsier og bildediagnostiske undersøkelser på forskjellige tidspunkter. Data om død og dødsårsaker ble hentet fra Statistisk sentralbyrå. Dødsårsakene ble klassifisert som kreft i fordøyelsesorganene, kreft utenom fordøyelsesorganene, hjerte- og karsykdom eller andre årsaker.

Etter 20 år var $14 \%$ av pasientene med Crohns sykdom døde, mot $13 \%$ av personene i kontrollgruppen. Det var ingen forskjell i totalmortalitet mellom pasientene med Crohns sykdom og kontrollpersonene (hasardratio 1,35; $95 \% \mathrm{KI} 0,94-1,94$ ). Det var heller ingen forskjeller når det gjaldt død av kreft totalt, kreft i fordøyelsesorganene eller hjerte- og karsykdom.

- Styrken i denne studien er den prospektive designen med svært høy oppmøteprosent og den longitudinelle oppfølgingen av en velkarakterisert pasientgruppe, sier artikkelens førsteforfatter Øistein Hovde. - Selv om antallet pasienter kan synes begrenset, dreier
Ordforklaringer

Crohns sykdom: En kronisk og ofte tilbakevendende betennelsessykdom som kan affisere hele fordøyelseskanalen. Arsaken(e) til sykdommen er ikke kjent, men arv, tarmens bakterieflora og ulike livsstilavhengige påvirkninger i disponert tarmslimhinne er de mest nærliggende forklaringer. Sykdommen angriper ofte i ung alder og kan innbefatte en rekke symptomer som diaré, magesmerter, blod i avføringen, vekttap og problemer med fistler.

Mortalitetsstudier i Norge: Med små og nære fagmiljøer og godt samarbeid i det kliniske daglige arbeidet er Norge ett av de landene som egner seg godt for denne type langtidsoppfølging av pasienter. Samtidig foreligger det gode og oversiktlige nasjonale registre hvor det er forholdsvis enkelt å spore pasientene, og det har vært lav mobilitet i befolkningen sammenliknet med mange andre land. det seg om et ikke ubetydelig antall tilfeller av en relativt sjelden sykdom. Crohns sykdom gir symptomer som hos en del kan skape problemer i det daglige liv og gi økt risiko for å bli operert, men denne undersøkelsen viser at det likevel ikke er økt risiko for død etter 20 års sykdom, sier Hovde.

\section{IBSEN-studien}

IBSEN-studien (Inflammatory Bowel

Disease South-Eastern Norway) ble startet i 1990 under ledelse av professorene Morten Vatn og Bjørn A. Moum, som begge har vært en drivkraft bak videreføringen av studien. Forskergruppen ble etablert i forbindelse med deltakelsen i en stor europeisk undersøkelse og har siden vært del av et bredt internasjonalt forskningssamarbeid. En lang rekke forskere har deltatt i hele eller deler av oppfølgingen. Det er publisert mer enn 60 originalartikler og avlagt åtte ph.d.-avhandlinger, mens ytterligere fem ph.d.-avhandlinger pågår eller er under planlegging. Forfatterne av den omtalte artikkelen er Øistein Hovde, Iril Kempski-Monstad, Milada Cvancarova Småstuen, Inger Camilla Solberg, Magne Henriksen, Jørgen Jahnsen, Njaal Stray og Bjørn A. Moum.

\section{Hanne Støre Valeur}

hanne.store.valeur@legeforeningen.no Tidsskriftet

\section{Litteratur}

1. Hovde O, Kempski-Monstad I, Småstuen MC et al. Mortality and causes of death in Crohn's disease: results from 20 years of follow-up in the IBSEN study. Gut 2013. E-publisert 6.6.

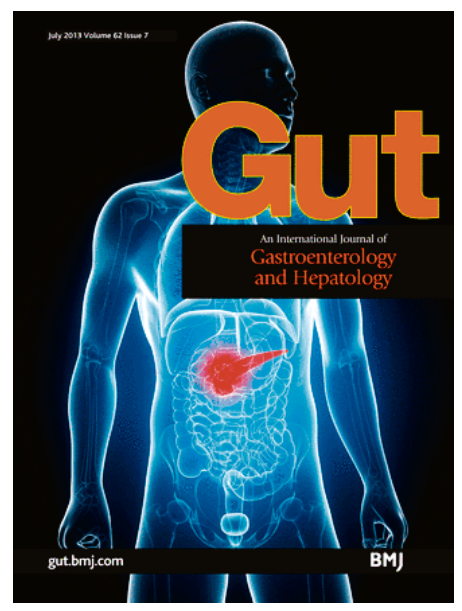

> Artikkelen ble nylig publisert i Gut, et av de mest anerkjente gastroenterologiske tidsskriftene. 